УДК 159.9:37.015

DOI https://doi.org/10.26661/2310-4368/2021-2-11

\title{
ФОРМУВАННЯ УЯВЛЕННЯ ПРО РОЗПОДІЛ РОЛЕЙ В СІМ'Ї СУЧАСНОЮ МОЛОДДЮ
}

\author{
Тавровецька Н. I. \\ кандидат психологічних наук, доиент, \\ доичент кафедри психології \\ Херсонський державний університет \\ вул. Університетська, 27, Херсон, Україна \\ orcid.org/0000-0002-9497-7386 \\ 1882181@gmail.com
} Ключові слова: сімейна
взаємодія, нуклерна сім'я,
батьківсько-дитячі стосунки,
сімейні ролі, психічна стать.
У статті представлено результати емпіричного дослідження уявлення сучасної молоді про розподіл ролей у сім'ї. Розглянуто аналіз розробленості питання з точки зору гендерного аспекту (психічної статі респондентів) та з урахуванням структури сім’ї респондентів (повні та неповні родини). Наведено результати за опитувальником «Індивідуальнотипологічний» (Л.М. Собчик) та опитувальником «Розподіл ролей у сім'ї» (Ю.С. Альошиної, Л.Я. Гозмана). Констатовано, що для сучасної молоді характерним є відсутність готовності брати на себе відповідальність за долю іншої людини, брати на себе батьківські обов'язки, не сформована установка на створення майбутньої сім'ї. Виявлено вплив гендерних стереотипів щодо розподілу сімейних ролей, статистично доведена відмініть у сприйнятті ролей в родинах між хлопцями та дівчатами, які виховуються у неповних родинах. Встановлено, що у групі респондентів в залежності від типу психічної статі $є$ розбіжності в уявленнях про тип сім'ї, а отже й про розподіл ролей у сім'ї. Дівчата 3 фемінним типом психічної статі більш схильні до вибору традиційного розподілу ролей у сім'ї, також є й проміжний тип. Фемінні хлопці обирають егалітарні та традиційні сім'ї. Найбільшу кількість таких респондентів склали хлопці 3 неповних родин. Їх фемінність можна пояснити саме вихованням матеріодиначки. Хлопці з маскуліним типом психічної статті, серед яких є як 3 повної родини так і ні обирають традиційний типу родини, а от дівчата проявляють амбівалентний вибір: егалітарна та традиційна родина. Молодь 3 андрогінним типом психічної статі обирають егалітарний тип сімейних стосунків та розподілу ролей. За результатами дослідження доведено, що для образу сучасної сім’ї в уявленнях молоді характерна присутність ознак різних типів сімейних стосунків: традиційні, проміжні та егалітарні сім’ї. У висновках представлені результати, які підтверджені сучасними аналогічними розвідками 3 даної проблематики. А саме, показано, що відсутній негативний вплив розлучення на відносини батька і дитини, що дитячо-батьківські відносини, у більшості відсотках результатів, залежать від типу психічної статі респондентів, від їх уявлення про образ шлюбного партнера та ті типи сімейних стосунків, які транслює батьківська сім'я. 


\title{
FORMATION OF AN IDEA OF THE DISTRIBUTION OF ROLES WITHIN THE FAMILY BY THE MODERN YOUTH
}

\author{
Tavrovetska N. I. \\ Candidate of Psychological Sciences, Associate Professor, \\ Associate Professor at the Department of Psychology \\ Kherson State University \\ Universytetska str., 27, Kherson, Ukraine \\ orcid.org/0000-0002-9497-7386 \\ 1882181@gmail.com
}

\begin{abstract}
Key words: family interaction, nuclear family, parent-child relations, family roles, mental gender.
\end{abstract}

\begin{abstract}
The article presents findings of the empirical study of the modern youth's vision of the distribution of roles within the family. The analysis of the development status of the issue under study from the perspective of gender (mental gender of respondents) and given a family composition of the respondents (nuclear and single-parent families) has been considered. The outcomes under "Individual and Typological Questionnaire" (L.M. Sobchyk) and "Questionnaire of Family Roles Distribution" (Iu. Ie. Aloshyna, L. Ia. Hozman) have been demonstrated. It has been stated that the modern youth are characterized by a lack of readiness to undertake for the life of another person, to assume parental duties and an unmatured attitude towards family creation. The author has found out the effect of gender stereotypes on the distribution of family roles, statistically proved the difference in taking family roles by boys and girls who are being upbrought in single-parent families. It has been established that depending on a type of mental gender, the group of respondents shows different ideas of a family type and thus of the roles' distribution within the family. Girls having a feminine type of mental gender tend to the conventional distribution of roles within the family; there is also a transitional type. Feminine boys choose egalitarian and traditional families. Most such respondents are boys from single-parent families. Their femininity is driven by the parenting of the single mother. Boys with a masculine type of mental gender who are both from nuclear families and aren't choose the traditional family; however, girls make an ambivalent choice. The youth with an androgynous type of mental gender choose an egalitarian type of family relations and distribution of roles. Based on the research findings, the author has justified that the youth's visions of the modern family are characterized by the features of different types of family relations: traditional, transitional, and egalitarian families. The conclusions covey the results which have been confirmed by modern similar research on the issue under study. In particular, it has been shown that there is no adverse effect on father-child relations due to divorce, as these relations mainly depend on a type of the respondents' mental gender, their idea of a marriage partner and the types of families relations supported by the family of origin.
\end{abstract}

Постановка проблеми. Актуальність вивчення уявлень молоді про розподіл ролей у родині, про шлюбно-сімейні відносини пов'язана 3 величезним значенням інституту сім'ї в суспільстві. Сучасні дослідження в області шлюбно-сімейних відносин свідчать про наявність безлічі актуальних невирішених питань, як про позитивні, так і негативні тенденції розвитку та трансформації родин. Існують різні точки зору щодо трансформацій, що відбуваються в інститутах сім’і та шлюбу. Прихильники еволюціоністського підходу переконані, що сім'я і шлюб розвиваються. Еволюціонують та набувають нових форм шлюбних відносин, які раніше не визнавались. 3 точки зору функціонального підходу сучасний стан і динаміка сім’ї та шлюбу в наш час, розцінюються як криза та руйнування усталених форм шлюбних відносин, деградація в уявленнях молоді про цінності родини. Ці два підходи є антагоністами i будуть існувати завжди, так як вони демонстру- 
ють два теоретико - емпіричних підходи у дослідженнях родини - «розвиту» та «гомеостазу» стосунків, ролей у родині та інше.

Аналіз публікацій присвячених вивченню уявлень молоді про сім'ю, про розподіл ролей у родинах, про батьківсько-дитячі взаємини не втрачає своєї актуальності і тому є підстави. В останні десятиліття традиційні шлюбно-сімейні відносини змінюються під впливом різних як зовнішніх i внутрішніх детермінант, які призводять до трансформації уявлень про шлюб та сім'ю у сучасної молоді. До внутрішніх чинників змін шлюбно-сімейних відносин відносять зростання індивідуальних потреб в ієрархії життєвих цінностей подружжя; збільшення цінності партнерських стосунків у шлюбі; втрачання відмінностей чоловічих і жіночих ролей в сім'ї; ослаблення родинних зв'язків та інше. Відбувається посилення таких процесів, як зниження престижу сім'ї, поширення альтернативних форм шлюбно-сімейних відносин, зниження потреби мати дітей, зростання числа родин, які виховують дітей у неповній родині.

Однак, ми не можемо ігнорувати й позитивні моменти трансформаційних процесів у родинних взаєминах, що впливають на формування уявлення про шлюб у сучасної молоді. Поява нових форм шлюбно-сімейних відносин має й прогресивне значення, створюючи умови для розвитку особистості, пристосування до сучасних вимог. Володіючи достатнім ступенем гнучкості, сім'я, змінюючи свій вигляд, здатна зберігати специфічні функції, знаходячи одночасно ресурси для гармонійного прийняття інновацій. Особливе ставлення та безпосередню виключність в цей процес демонструє молоде покоління. У розгляді формування уявлень молоді про шлюбно-сімейні відносини особливе місце займає вивчення розподілу ролей в сім'ї, ставлення до родини, шлюбу, вплив гендерних стереотипів.

Мета статті: представити результати емпіричного дослідження уявлення сучасної молоді про розподіл ролей у сім’ї з різною структурою 9повні та неповні родини); здійснити аналіз зв'язку психічної статі та спрямування на тип сім'ї.

Виклад основного матеріалу дослідження.

Формування уявлення про об'єкт, суб'єкт, подію, результат та інше - складний та тривалий процес. В.М. Фомічова наголошує на необхідності чітко відрізняти питання щодо різниці між загальними уявленнями, як процесом, та соціальними уявленнями. Уявлення по відношенню до фізичного об'єкту - процес, який закінчується результатом і має свої критерії та характеристики, а соціальні уявлення - $\epsilon$ результатом взаємодії та спілкування з іншими людьми, по відношенню до соціальних об'єктів, явищ. Саме соціальні уяв- лення $\epsilon$ підгрунтям та основою для формування суджень та висновків, та регуляторів відповідної соціальної поведінки. Звідси, формування уявлення й про розподіл ролей у родині, про шлюбні відносини [9, с. 91].

Розглянемо 4 групи уявлень, характерних серед молодих осіб, які не мають ще досвіду у подружньому житті, які надає Л. Москвічева: 1) «затишне й тепле коло домашнього спілкування», тобто у сім'ї панує кохання та взаємопорозуміння; 2) «фортеця, сховище», тобто надійний захист від негараздів зовнішнього світу; 3) «незмінний організм, дерево», тобто сім'я є цілісним організмом, це допомога та підтримка родичів у функціонуванні сім’ї; 4) «взаємну відповідальність», тобто уявлення про майбутню сім'ю, де кожен член родини несе відповідальність один за одного [6].

На процес формування уявлення про розподіл ролей у сім'і, про взаємним стосунки між дітьми та батьками головним чином впливає образ своєї, батьківської родини. За результатами дослідження Е. Козловської, образ та уявлення про майбутні сім’ї у молоді залежить від рівня збігу їх образів родини з батьківським образом сім'і, що є базовим компонентом [3].

У емпіричному дослідженні авторів С.А. Масленнікова, Г.I. Непряхіна уявлення молоді про шлюбно-сімейні відносини пов'язані з їх уявленнями про розподіл ролей в сім'ї, ціннісними орієнтаціями, наявністю досвіду шлюбно-сімейних відносин і виражаються через любов, прихильність і інтимність відносин. Авторки констатують, що уявлення про шлюбно-сімейні відносини у молоді зараз є суперечливими. Однак для всіх молодих людей почуття любові є підставою для створення сім'ї і шлюбу. Для сучасної молоді любов, емоційна прив'язаність, продовження роду залишається значимим аспектом шлюбно-сімейних відносин, які відповідають глибоко особистим потребам людей [5, с. 180].

Інше емпіричне дослідження присвячене вивченню психологічного змісту уявлень студентської молоді про сімейні ролі шлюбних партнерів. За результатами дослідження, авторка Д.С. Карпова робить висновки, що значною мірою уявлення молоді формуються на основі двох механізмів: трансляції та копіювання батьківської моделі поведінки у повних родинах) та компенсації (заміщення однієї з ролей батьків у неповних родинах). Таким чином, в основу уявлення про розподіл сімейних ролей покладений сімейний сценарій, особливості структури сім'ї та статева ідентичність молоді [2, с. 10].

На формування уявлення молоді про майбутню родину та особливий вплив батьків різної статті звертають увагу й зарубіжні дослідники. Так у своїх чисельних дослідженнях Р. А. Cowan наво- 
дить результати впливу батьків, особливо чоловіків, на формування адекватної самооцінки підлітків, відсутність міжособистісних конфліктів 3 однолітками; виявляє високий рівень задоволеності партнерів шлюбом, що впливає на формування образу майбутньої сім’ї у дітей [10, с. 172]. Інші дослідники, Popov L. M. \& lesanmi Ruth A., констатують, що в сімейному контексті погляди на виховання дітей і відносини між батьками i дітьми розширилися і тепер включають батьків як активних менеджерів соціального середовища дитини. Гармонійна взаємодія між батьками та їхніми дітьми, гарне сімейне оточення, емоційний аспект мають позитивний характер а підтримку для дитини підчас формування уявлень про шлюб. Хоча деякі дослідження показують негативний вплив розлучення на відносини батька і дитини, неясно, чи $є$ ці ефекти $є$ додатковими 3 точки зору дітей. Авторами доведено, що хороші відносини між батьками та їхніми дітьми покращують загальне самопочуття (у дітей) і призводять до поліпшення соціального життя, захищають від емоційних потрясінь і самогубств [11, с. 253].

У своєму емпіричному дослідженні ми спиралися саме на ці наукові дослідження та намагалися з'ясувати вплив структури родини (повної та неповної) на формування уявлень молоді про шлюбний розподіл ролей. На емпіричному етапі дослідження застосовано опитувальник «Індивідуально-типологічний опитувальник» (Л.М. Собчик). Представлена типологія індивідуально-особистісних якостей грунтується на цілісному розумінні особистості з позиції теорії домінуючих тенденцій, які наявні та проникають на всі рівні особистості. Для дослідження розподілу ролей у родині респондентами 3 різним родинним статусом ми застосували опитувальник «Розподіл ролей у сім'ї» (Ю.С. Альошиної, Л.Я. Гозмана), який призначений для вивчення установок особистості стосовно розподілу сімейних ролей між чоловіком та жінкою. Складається з 21 твердження, які дають змогу виявити установки молодих людей стосовно розподілу ролей в сферах сімейного життя: 1) виховання дітей; 2) матеріальне забезпечення сім’ $1 ; 3$ ) підтримка емоційного клімату в сім'ї; 4) організація розваг; 5) виконання ролі «господаря» / «господарки»; 6) відповідальність за задоволення інтимними стосунками; 7) організація сімейної субкультури. Дослідження проводилось серед учнів 10-х класів закладів середньої освіти м. Херсона. Загальна кількість осіб - 63 (30 хлопців та 33 дівчини). У дослідженні за критерій відбору до складу вибірки ми застосували родинну структуру, а саме повний складу сім'ї чи неповний (відсутність одного з батьків). Ми припустили, що формування уявлення про рольовий розподіл в сім'ї буде мате різницю в залежності від складу сім'ї, а також буде обумовлюватися типом психічної статі. До складу вибірки 1 (респонденти з повних родин) увійшли - 33 особи, до складу вибірки 2 (неповна родина) - 30 .

За результатами дослідження домінуючих тенденцій індивідуально-типологічних рис за опитувальником Л.М. Собчик ми виявили ступінь ідентифікації сучасної молоді, наших респондентів 3 традиційною культурною і соціальною роллю чоловіка або жінки. Так як ми припустили вплив психічної статі на формування уявлення про розподіл ролей в сім'ї то й проаналізуємо отримані результати. Сім'я виступає моделлю визначеного стилю життя і $\epsilon$ джерелом формування важливих життєвих цінностей й переконань у молоді. Сімейна система формує певний рівень вияву індивідуальності й автономії, підкріплюючи ті чи інші зразки статево-рольової поведінки. Існуючий поділ людей на чоловіків і жінок - це установка сприйняття розходжень між людьми. Сьогодні біологи ставлять під сумнів обгрунтованість чіткого поділу людей тільки на дві протилежні статі. Вони пропонують кілька рівнів сексуальної організації людини: генетична стать; гонадна стать; морфологічна стать; церебральна стать [7, с. 154]. Опитувальник дав змогу визначити маскулінність-фемінінність особистості в традиційному, стереотипному його розумінні. Аналізуючи результати можна сказати, що хлопці та дівчата поділяються на три групи, а саме: фемінінну, маскулінну, андрогенну. Особливістю такого поділу є те, що хлопці рівномірно розділились на фемінінну та маскулінну групи, а жінки мають свою особливість. У жіночій групі маскулінність нижча ніж фемінінність. Жінки більш андрогенні ніж чоловіки. Такий результат свідчить про те, що жінки швидше можуть змінювати тип поведінки в залежності від ситуації, чоловіки діляться на фемінних та маскулінних і менша частина може адекватно повести себе у будь-якій ситуації.

У більшості опитуваних (34\%) показники фемінності підвищені, що свідчить про те, що статево-рольова ідентифікація, як хлопців так і дівчат, здійснюється з відхиленням від традиційних стереотипних норм маскулінності-фемінінності. За результатами дослідження у $42 \%$ опитуваних статево-рольова ідентифікація відбувається без таких відхилень; у 24\% показники помірні, а у $26 \%$ опитуваних показники свідчать про акцентуації у статево-рольових характеристиках, що свідчить, про те, що статево-рольова ідентифікація відбувається за нетрадиційними схемами маскулінності-фемінінності. Отримані результати підтверджуються сучасними науковими дослідженнями, а саме, що однією 3 тенденцій розвитку сім'ї є злам гендерних стереотипів. Зі змінами 
позиції жінки у суспільстві чоловік втрачає безперечне право «маскулінності», тобто об'єктивно закріплюється перехід до біархальної сім’ї. Для уявлень молоді про сучасну сім'ю характерно наявність одночасно різних типів сімейних стосунків, як 3 традиційним укладом, так і нових, гендерно-нейтральних [8, с. 150]. Таким чином ми визначили, що маскулінна ідентичність молоді значима у андрогенній та маскулінній групі, але відсутня у фемінній.

Наступною методикою для визначення розподілу ролей у родині респондентами 3 різним родинним статусом ми застосували опитувальник «Розподіл ролей у сім’ї» (Ю.С. Альошиної, Л.Я. Гозмана). На рис. 1 представлено кількісні результати середніх значень ідеального розподілу ролей у сім’ї молоддю $з$ повних родин.
Як бачимо 3 рис. 1, дівчата 3 повних родин, на відміну від хлопців, більш схильні до цього, щоб сімейні ролі ділилися 3 ними порівну, проте вихованню дітей вони готові приділити більше уваги. Дівчата з повних родин вважають, що матеріальне забезпечення сім’і повинні здійснювати більше чоловіки. Суттєво іншими є результати у групі респондентів $з$ неповних родин (рис. 2).

Аналіз рисунків дає підстави стверджувати, що переважна більшість молоді (хлопців та дівчат) 3 повних родин, на відміну від молоді 3 неповних родин, мають бажання спільно розділити більшість сімейних ролей без поділу їх на «жіночі» i «чоловічі». Але, що стосується функцій пов’язаних 3 вихованням дітей та домашнім господарством, то, навіть, хлопці з повних родин не бажають їх поділяти зі своїми майбутніми дружинами.

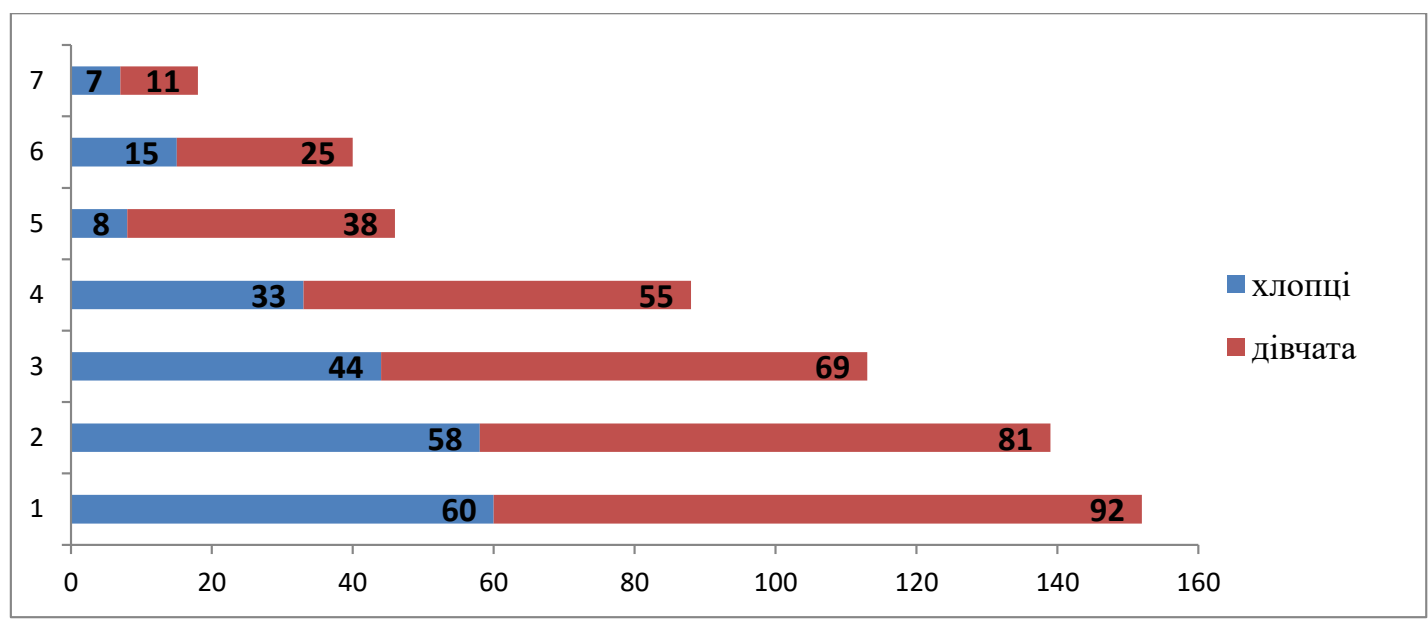

Рис. 1. Розподіл сімейних ролей за уявленням молоді з повної родини

Примітка: 1. Організація сімейної субкультури; 2. Сексуальний партнер; 3. Роль господаря (господині); 4. Організація розваг; 5. Емоційний клімат; 6. Матеріальне забезпечення; 7. Виховання дітей.

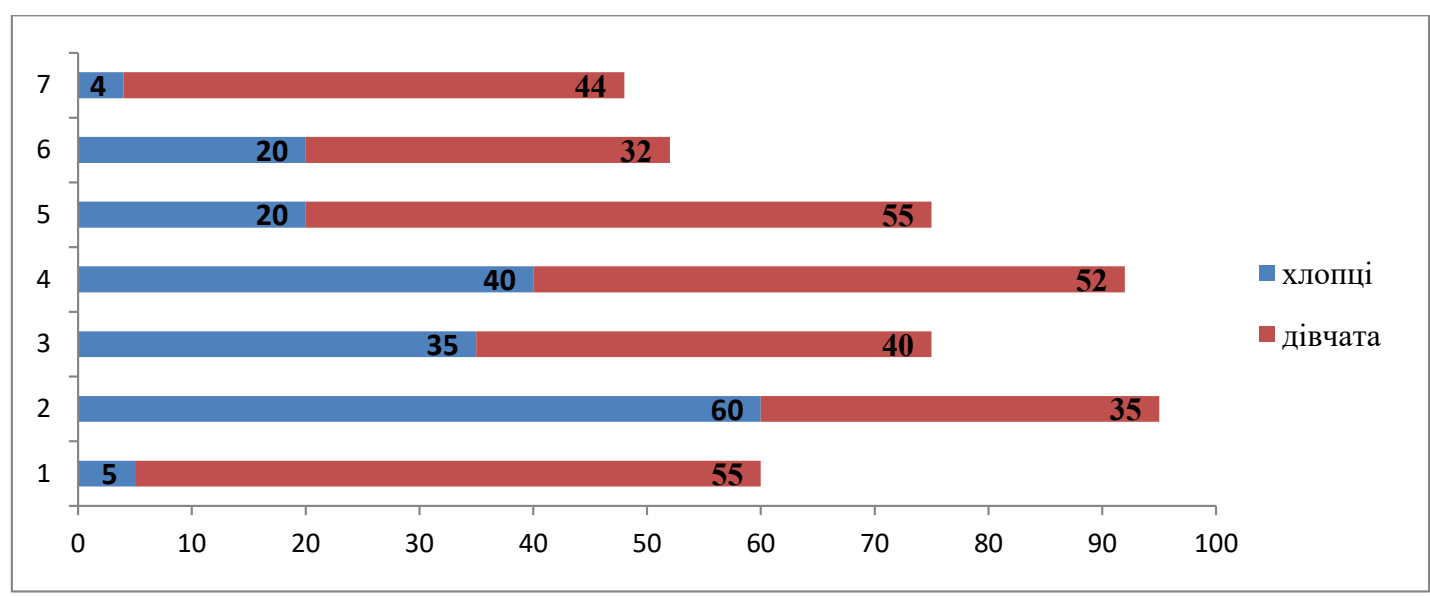

Рис. 2. Розподіл сімейних ролей за уявленням молоді з неповної родини

Примітка: 1. Організація сімейної субкультури; 2. Сексуальний партнер; 3. Роль господаря (господині); 4. Організація розваг; 5. Емоційний клімат; 6. Матеріальне забезпечення; 7. Виховання дітей. 
А хлопці з неповних родин вважають, що більшу частину сімейних обов'язків повинна виконувати жінка. Такі результати ми можемо пояснити тим, що у неповних сім'ях є деструктивний розподіл ролей та функцій. Зазвичай неповна родина - це жінка 3 дітьми, яка виконує всі сімейні ролі, й традиційно «жіночі», й традиційно «чоловічі». Такий розподіл ролей сприймають підлітки 3 цих родин як взірець, і ми можемо припустити, що й будувати свої родину (особливо хлопці, у яких відсутній взірець образа батька, господаря) будуть й у своїх родинах. Отримані результати підтверджуються й рядом сучасних аналогічних досліджень. Зокрема, I. Крупник у своєму емпіричному дослідженні присвяченому висвітленню уявлення про майбутню родину серед молоді, образу «ідеальний шлюбний партнер» наголошує на впливі гендерних стереотипів, якими керується сучасна молодь. Образ «справжнього чоловіка» уявляють як відповідальний, сміливий, рішучий, розумний а образ «справжньої дружини» - приваблива, гарна господиня, турботлива. Автор зазначає, що сучасна молодь у своїх уявленнях схильна до шаблонності та стереотипності у образі чоловіка та дружини. Уявлення є занадто «ідеальні», навіть абстрактні. Такі результати свідчать про сучасні трансформаційні процеси сім'ї, девальвацію цінностей сім'ї, появу нових форм шлюбних відносин та інше $[4$, с. 341$]$.

Підчас інтерпретації результатів дослідження, з'ясовано, що стереотипні уявлення про розподіл ролей у сім'ї більш виражені у підлітків 3 неповних сімей. У відповідності зі стереотипними уявленнями про розподіл ролей у сім’ї хлопці з неповних сімей мають уявлення, що основну частину сімейних обов'язків повинна виконувати дружина, а чоловік повинен забезпечувати матеріальне благополуччя сім'ї, здійснювати контакти з соціумом. Цікавим $\epsilon$ результат у дівчат, які взяли на себе виконання функцій по матеріальному забезпеченню сім'ї. Такі результати є свідчення прийняття дівчатами егалітарних відносин у родинах.

Для встановлення статистично значущих показників вибірки порівнювалися за допомогою $\mathrm{U}$-критерію Манна - Уітні. Отримані результати дослідження наведені в таблиці 1.
За підсумками дослідження ми дійшли висновку, що між вибірками респондентів повних родин менше розходжень, ніж між вибірками респондентів 3 неповних родин, тобто гармонійне поєднання при розподілі ролей ми констатуємо у повних родинах.

Виходячи із характеру розподілу сімейних ролей, виділяють три типи сімей: традиційні, егалітарні і проміжні. Традиційні сім’ї - це сім'ї, де всі домашні обов'язки ділять на «чоловічі» $\mathrm{i}$ «жіночі» і більшу частину цих обов'язків виконує жінка, тобто ми можемо говорити про статевотипізований, жорсткий розподіл ролей. Егалітарні сім'ї характеризуються спільним поділом сімейних ролей без поділу їх на чоловічі і жіночі, таким сім'ям властива взаємозаміна подружжя в домашніх справах. В сім'ях проміжного типу не виражений типовий варіант розподілу внутрішньо сімейних ролей, й таки сім'ї $€$ найбільш вразливими до впливів соціуму.

У результаті дослідження виявилось, що сучасної молоді відсутні готовність брати на себе відповідальність за долю іншої людини, зміцнювати подружній союз, брати на себе батьківські обов'язки, не сформована установка на створення майбутньої сім'ї. Більше $65 \%$ респондентів вважають, що у сім'ї має панувати патріархат; 3,2\% дівчат висловились за те, що головою сімейства має бути чоловік, такої ж думки дотримується кожен третій юнак. На домінування в сім'ї, на думку всіх опитаних, не впливає рівень освіти, життєвий досвід партнера (про це заявило 22,13\% хлопців та 17,44\% дівчат). Неузгодженість сімейних цінностей у сфері батьківського виховання дітей зумовлена певною невпевненістю частини дівчат щодо серйозного ставлення чоловіків до виховання дітей, виконання ними батьківських функцій.

Щоб встановити, чи існує зв'язок між типами сімей і уявленням про розподіл ролей в сім'ї та типом психічної статті ми проаналізували результати відповідей за опитувальниками.

Аналіз таблиці 2 доводить нам, що у групі респондентів в залежності від типу психічної статі $€$ розбіжності в уявленнях про тип сім'ї, а отже й про розподіл ролей у сім'ї. Дівчата 3 фемінним типом психічної статі більш схильні до вибору

Таблиця 1

Рівень відмінностей між чоловіками та жінками при розподілі ролей

\begin{tabular}{|l|c|c|}
\hline \multicolumn{1}{|c|}{ Сімейні ролі } & Молодь з повних родин & Молодь 3 неповних родин \\
\hline Виховання дітей & - & $\mathrm{U}=649(\mathrm{p} \leq 0,01)$ \\
\hline Матеріальне забезпечення сім'ї & - & - \\
\hline Підтримування емоційного клімату в сім'ї & $\mathrm{U}=948(\mathrm{p} \leq 0,05)$ & - \\
\hline Організація розваг & - & $\mathrm{U}=881(\mathrm{p} \leq 0,01)$ \\
\hline Виконання ролі «господаря» / «господарки» & $\mathrm{U}=735(\mathrm{p} \leq 0,01)$ & $\mathrm{U}=845(\mathrm{p} \leq 0,01)$ \\
\hline Відповідальність за задоволення інтимних відносин & $\mathrm{U}=851(\mathrm{p} \leq 0,05)$ & $\mathrm{U}=774(\mathrm{p} \leq 0,05)$ \\
\hline Організація сімейної субкультури & - & $\mathrm{U}=633(\mathrm{p} \leq 0,05)$ \\
\hline
\end{tabular}


Таблиця 2

Розподіл уявлень молоді щодо сімейних ролей в залежності від типу психічної статті

\begin{tabular}{|c|c|c|c|c|c|c|}
\hline \multirow{2}{*}{ Група Тип сім'ї } & \multicolumn{6}{|c|}{ Шкали } \\
\hline & \multicolumn{2}{|c|}{ Фемінна } & \multicolumn{2}{|c|}{ Маскулінна } & \multicolumn{2}{|c|}{ Андрогінна } \\
\hline стать & Хлопці & Дівчини & Хлопці & Дівчини & Хлопці & Дівчини \\
\hline Егалітарні сім’ї & $11,2 \%$ & $8,6 \%$ & $8,6 \%$ & $14,6 \%$ & $14,5 \%$ & $13,8 \%$ \\
\hline Проміжні сім’ї & $12,1 \%$ & $13,6 \%$ & $10,4 \%$ & $8,8 \%$ & $10,2 \%$ & $10,6 \%$ \\
\hline Традиційні сім’ї & $8,2 \%$ & $12,6 \%$ & $16,6 \%$ & $12,7 \%$ & $8,2 \%$ & $4,7 \%$ \\
\hline
\end{tabular}

традиційного розподілу ролей у сім'ї, також $є$ й проміжний тип. Тобто дівчата $з$ таким типом більш схильні коритись, будувати сімейні стосунки за традиційним (патріархальним) укладом. Фемінні хлопці у нашому дослідженні обирають егалітарні та традиційні сім'ї. Найбільшу кількість таких респондентів склали хлопці з неповних родин, і тому їх уявлення про рольовий розподіл у сім'ї $є$ викривленим, адже вони не мають постійного чоловічого образу для наслідування, але мають приклади чоловічого образу у соціумі, які формуються завдяки гендерним стереотипам. Ïх фемінність можна пояснити саме вихованням матері-одиначки.

Для порівняння $\epsilon$ результати хлопців 3 маскуліним типом психічної статті, серед яких є як 3 повної родини так і ні. Всі вони тяжіють до традиційного типу родини, а от дівчата проявляють амбівалентний вибір $-\epsilon$ високі показники й егалітарної та традиційної родини. Підлітки з андрогінним типом психічної статі обирають егалітарний тип сімейних стосунків та розподілу ролей. За висловлюванням та емпіричним дослідженням С. Бем, андрогінність - це поєднання кращих, найбільш соціально-адаптованих рис особистості чоловічої і жіночої статі [1, с. 248]. Такий тип уявлення у підлітків про розподіл ролей у сім'ї $\epsilon$, на нашу думку, є гармонійним, позитивним, так як саме він надасть можливість розподіляти ролі, функції, обов'язки у родині не згідно біологічної статі, а згідно особистих уподобань, можливо- стей, прагнень. А це, у свою чергу, зробить сім'ю більш адаптованою у соціальних взаєминах.

Висновки. Розподіл уявлень молоді щодо сімейних ролей свідчить про процеси перебудови у шлюбних відносинах, у формуванні цінностей родини та свого місця у сімейних стосунках. Ряд останніх досліджень свідчать про поступове набуття ознак егалітарності, тобто: готовність та здатність до взаємозаміни у виконанні сімейних функцій та ролей, більша гнучкість поведінки у сімейних конфліктах та прийняття нової ролі, що не відповідає біологічній статі, прийняття відповідальності кожного члена сім'ї. Однак, у нашому досліджені, ми констатуємо лише тенденції до егалітарних стосунків, спостерігаємо процес вирівнювання функцій шлюбних партнерів, що особливо помітно у відходженні від стереотипних уявлень у виконанні ролей батька і матері. Для образу сучасної сім'ї в уявленнях молоді характерна присутність ознак різних типів сімейних стосунків, як 3 традиційним укладом, так i нових, егалітарних взаємин. Отже, нами було сформульовано висновок, що уявлення молоді про сімейні ролі характеризується особливим змістом, структурою та залежить від типу психічної статі та статі батьків, з якими виховується молодь. Зважаючи на такі висновки, серед подальших розвідок та перспектив дослідження, з'ясування впливу нових форм шлюбних відносин на уявлення образу родини серед молоді, визначення тенденцій та закономірностей у цьому процесі.

\section{ЛІТЕРАТУРА}

1. Бем С. Линзы гендера: Трансформация взглядов на проблему неравенства полов. М., 2004. 336 с.

2. Карпова Д.Є. Психологічний зміст та функції уявлень студентської молоді про сімейні ролі шлюбних партнерів. Науковий вісник Херсонського державного університету: Серія Психологічні науки, 2017, вип. 2. Том. 2. С. 8-14.

3. Козловська Е.В. Психологічна готовність молодого подружжя до гармонізації стосунків : автореф. дис. ... канд. психол. наук: 19.00.05. Київ, 2011.18 с.

4. Крупник I. Образи «ідеальних» чоловіка та дружини в уявленнях молоді: теорія і практика. Психологічні ресурси в умовах життєвої та суспільної кризи: сочіальний та особистісний виміри: колективна монографія. Херсон, 2021. С. 336.

5. Масленникова С.А., Непряхина А.И. Изучение представлений современной молодежи о брачно-семейных отношениях. Человеческий капитал. 2019. № 5(125). С. 177-184. DOI: 10.25629/ HC.2019.05.22

6. Москвичева Н.Л. Семья в системе ценностных ориентаций личности студента: автореф. дис. ... канд. психол. наук: 19.00.11. СПб., 2000. 20 с. 
7. Мушкевич М. І., Федоренко Р. П., Магдисюк Л. І., Дучимінська Т. І. Психологія молодої сім'ї: монографія. Луцьк : Вежа-Друк, 2018. 235 с.

8. Протас О. Л. Трансформація інституту сім'ї як чинник умов сімейного виховання. Вісник післядипломної освіти. Випуск 11(40) «Серія «Педагогічні науки». 2020. С. 136-153. https://doi.org/10.32405/ 2218-7650-2020-11(40)-136-153

9. Фомічова В.М. Уявлення молоді про чинники щасливого подружнього життя. Актуальні проблеми соиіології, психології, педагогіки. : зб. наук. пр. К., 2015 № 2 (27). С. 90-96.

10. Cowan Philip A. The Role of Parental Relationships in Children's Well-Being: A Modest Set of Proposals for Improving the Lives of Children. Human Development 2019; 62. P.171-174. DOI: 10.1159/000500173

11. Popov Leonid M. \& Ilesanmi Ruth A. Parent-Child Relationship: Peculiarities and Outcome. Review of European Studies; Vol. 7, No. 5; 2015. C. 253-263. DOI:10.5539/res.v7n5p253

\section{REFERENCES}

1. Bem, S. (2004). Linzyi gendera: Transformatsiya vzglyadov na problemu neravenstva polov [Gender Lenses: Transforming Views on Gender Inequality]. M., 336. [in Russian].

2. Karpova, D.Ie. (2017). Psykholohichnyi zmist ta funktsii uiavlen studentskoi molodi pro simeini roli shliubnykh partneriv [Psychological meaning and function concepts of the role of family marriage partners]. Naukovyi visnyk Khersonskoho deravnoho universytetu: Seriia Psykholohichni nauky - Scientific Bulletin of Kherson State University: Psychological Sciences Series vyp.2. tom.2 S. 8-14. [in Ukrainian].

3. Kozlovska, E.V. (2011). Psykholohichna hotovnist molodoho podruzhzhia do harmonizatsii stosunkiv [Psychological readiness of a young couple to harmonize relations]: Extended abstract of candidate's thesis. Kyiv. [in Ukrainian].

4. Krupnyk, I. (2021). Obrazy «idealnykh» cholovika ta druzhyny v uiavlenniakh molodi: teoriia i praktyka [Images of "ideal" husband and wife in the minds of young people: theory and practice]. Psykholohichni resursy v umovakh zhyttievoi ta suspilnoi kryzy: sotsialnyi ta osobystisnyi vymiry - Psychological resources in a life and social crisis: social and personal dimensions : kolektyvna monohrafiia. Kherson. S. 336. [in Ukrainian].

5. Maslennikova, S.A. \& Nepryahina, A.I. (2019). Izuchenie predstavleniy sovremennoy molodezhi o brachno-semeynyih otnosheniyah [The study of the representations of modern youth about marriage and family relations] Chelovecheskiy capital - Human capital. № 5(125). S. 177-184. [in Russian].

6. Moskvicheva, N.L. (2000). Semya v sisteme tsennostnyih orientatsiy lichnosti studenta [Family in the system of value orientations of the student's personality]: Extended abstract of candidate's thesis. SPb. [in Russian].

7. Mushkevych, M. I., Fedorenko R. P., Mahdysiuk L. I., \& Duchyminska T. I. (2018). Psykholohiia molodoi simi [Psychology of a young family]. Lutsk : Vezha-Druk, [in Ukrainian].

8. Protas, O. L. (2020). Transformatsiia instytutu simi yak chynnyk umov simeinoho vykhovannia [Transformation of family institution as a factor of conditions of family upbringing]. Visnyk pisliadyplomnoi osvity. (Seriia Pedahohichni nauky) - Bulletin of Postgraduate education. (Educational Sciences Series). Issue 11(40). S.136-153. [in Ukrainian].

9. Fomichova, V.M. (2015). Uiavlennia molodi pro chynnyky shchaslyvoho podruzhnoho zhyttia [Young people's ideas about the factors of a happy married life]. Aktualni problemy sotsiolohii, psykholohii, pedahohiky - Actual problems of sociology, psychology, pedagogy. K., № 2 (27). S. 90-96. [in Ukrainian].

10. Cowan, Philip A. (2019). The Role of Parental Relationships in Children's Well-Being: A Modest Set of Proposals for Improving the Lives of Children. Human Development; 62. P.171-174. DOI: $10.1159 / 000500173$

11. Popov, L. M. \& Ilesanmi Ruth A. (2015). Parent-Child Relationship: Peculiarities and Outcome. Review of European Studies; Vol. 7, No. 5. P.253-263. DOI:10.5539/res.v7n5p253 